\title{
Correction to: Answering biological questions by analysis of the strawberry metabolome
}

\author{
Annika Haugeneder ${ }^{1} \cdot$ Johanna Trinkl $^{1} \cdot$ Katja Härtl $^{1}$ (D) Thomas Hoffmann $^{1} \cdot$ James William Allwood $^{2}$ (D) \\ Wilfried Schwab ${ }^{1}$ (D)
}

Published online: 9 March 2019

(c) The Author(s) 2019

\section{Correction to: Metabolomics (2018) 14:145 https://doi.org/10.1007/s11306-018-1441-x}

The article Answering biological questions by analysis of the strawberry metabolome, written by Annika Haugeneder, Johanna Trinkl, Katja Härtl, Thomas Hoffman, James William Allwood and Wilfred Schwab, was originally published electronically on the publisher's internet portal (currently SpringerLink) on 26 October, 2018 without open access. After publication in volume 14. Issue 11, Citation Id 145, with the author(s)' decision to opt for Open Choice the copyright of the article changed on 20 December, 2018 to (c) The Author(s) [2019] and the article is forthwith distributed under the terms of the Creative Commons Attribution 4.0 International License (http://creativecommons.org/licenses/ by/4.0/), which permits use, duplication, adaptation, distribution and reproduction in any medium or format, as long as you give appropriate credit to the original author(s) and the source, provide a link to the Creative Commons license and indicate if changes were made.

The original article has been corrected.

The original article can be found online at https://doi.org/10.1007/ s11306-018-1441-x.

Wilfried Schwab

wilfried.schwab@tum.de

1 Biotechnology of Natural Products, Technische Universität München, Liesel-Beckmann-Str. 1, 85354 Freising, Germany

2 Environmental and Biochemical Sciences Group, The James Hutton Institute, Invergowrie, Dundee, Scotland DD2 5DA, UK
Open Access This article is distributed under the terms of the Creative Commons Attribution 4.0 International License (http://creativeco mmons.org/licenses/by/4.0/), which permits unrestricted use, distribution, and reproduction in any medium, provided you give appropriate credit to the original author(s) and the source, provide a link to the Creative Commons license, and indicate if changes were made.

Publisher's Note Springer Nature remains neutral with regard to jurisdictional claims in published maps and institutional affiliations. 